-impact is "nebulous", says John Moore of the Aaron Diamond AIDS Research Center in New York, chair of OAR's vaccine research and development committee. "If that is the case, why do it?"

The letter, drafted by Moore, says that before the creation of the OAR, the funding of AIDS research at NIH "was inefficient, leading to an uncoordinated, duplicated and disorganized allocation of federal funds".

Under the eye of Levine, the OAR is reviewing this system. It will report to Congress in September, in preparation for a major overhaul of the type of AIDS research undertaken at NIH. The scientists say Congress should delay any decision about the office until the report has been submitted.

But the panel's action has not come as a surprise. "We knew Republicans didn't hold OAR in favour," says Moore. Furthermore, he points out, the influence of AIDS activists with Republicans is considerably less than that of others fighting to defend the NIH budget.

Spencer Cox, of the Treatment Action Group in New York, says that his group is particularly concerned about the prospect that control over AIDS research funding will be returned to Anthony Fauci, director of the National Institute of Allergy and Infectious Diseases which conducts about half of AIDS research at NIH.

"Paul emphasizes basic, baseline research," says Cox, claiming that this contrasts with Fauci's earlier approach when he held sway over AIDS research funding at the institute. Cox's comments suggest that the latest congressional moves have rekindled the animosity previously directed at Fauci by some members of the AIDS community.

Adrianne Appel

\section{Serco wins physics laboratory contract}

London. Ian Lang, Britain's secretary of state for trade and industry, announced last week that a five-year contract to manage Britain's National Physical Laboratory NPL) has been awarded to a consortium led by Serco, a contract management group first created in 1929 by the US company RCA to manage its cinemas in Britain.

In a written statement to the House of Commons, Lang said that the consortium, which also includes AEA Technology and Loughborough University, will be expected to extend NPL's commercial work without compromising its status as a world centre of excellence in metrology.

Serco was bought out by its managers in 1987, and has grown rapidly as the government has privatized the management of public services. The defence industry accounts for 36 per cent of its business. But the group's other interests range from running a prison in Doncaster in the north of England to looking after 17,000 parking meters in Hong Kong.

\title{
Major claims policy changes will 'strengthen' UK science
}

London. The British government found itself having to fight hard last week to justify its decision to move the Office of Science and Technology (OST) out of the Cabinet Office and into the Department of Trade and Industry (DTI).

Faced with a continuing stream of protest from both the scientific and political communities, Ian Taylor, an under-secretary of state within the DTI and given responsibility for science and technology, said that the science office was being moved "closer to the effective heart of government".

Taylor, whose rank is usually referred to as that of junior minister, also dismissed concerns that the result would inevitably be a reduced commitment to longterm, fundamental research. His remarks came shortly after John Major, the prime minister, had told the House of Commons that the purpose of the move was "to strengthen the con- Taylor: arrival received tribution of science, a cautious welcome. engineering and technology to long-term wealth creation."

But the scientific community remains suspicious. The pressure group Save British Science (SBS), for example, stayed on the offensive. One of its co-founders, Dennis Noble of the University of Oxford, criticized the move in a speech to the Physiological Society as "disastrous", claiming that it could, if handled insensitively, "quite simply strangle the creativity of the science base."

Within Parliament itself, criticism was not confined to the opposition Labour Party which said that it remained committed to an independent OST - but also came from the Conservative backbenches. In particular, Robert Jackson, who had been a junior minister in the Cabinet Office during the preparation of the government's white paper on science in 1993, wrote in an article in the Financial Times that the move represented "an alarming triumph of short-termism".

Taylor vigorously disputes such criticism, emphasizing the importance of assuring that "there is an interaction between what is happening in industry and what is happening in science", and thus the advantage to science - with its mission to improve the performance of the national economy and raise the quality of life - in being placed within the DTI.

Taylor was parliamentary private secretary to William Waldegrave, the cabinet minister responsible for science from 1992 to 1994 . He says that part of his role will be to convince industry of the importance of long-term, 'blue-sky' research. "This is the most exciting portfolio in government, and the one that has the greatest opportunities," he says.

In response to concern expressed by, among others, Sir Arnold Wolfendale, former astronomer royal and president of the Institute of Physics, over the future of the government's support for the public understanding of science - an increasingly significant role of the OST - Taylor says that it "fits in beautifully" with his current efforts to promote awareness of the importance of industrial innovation, for example among school science teachers.

Taylor's appointment has come as some relief to the scientific community. He was previously under-secretary of state for trade and technology, a position that included responsibility for DTI's involvement in topics such as information technology and space, and is widely seen as both conscientious and approachable.

"We certainly welcome Taylor as someone who looks as if he will take a serious interest in his responsibilities," says John Mulvey, secretary of SBS. Space scientists, responsibility for whose field had previously been split between the DTI and the research councils, have given the appointment a particular welcome.

But Mulvey and other critics also point out that, however great Taylor's enthusiasm, his powers as a junior minister - for example, in his ability to influence the research agendas of other government departments - are likely to be limited.

Furthermore, by allocating responsibility for science to what is widely seen as a "third rank" ministerial post, the government may, according to some observers, have made it difficult for the House of Commons Select Committee on Science and Technology to make the case for its continued existence.

Taylor himself says that he considers the committee - which could in principle disappear under a post-1992 rule that the responsibilities of such committees must mirror those of government departments, placing science under a broader trade and industry committee (see Nature 376, 103; 1995) - plays an important role in reviewing science related issues.

Sir Giles Shaw, Conservative MP for Pudsey and chairman of the committee, says he is optimistic that it will survive, partly because of its unique transdepartmental role, and partly because the long-term issues it tackles, such as human genetics (see page 202), are relatively non-political.

David Dickson 